\title{
LENGTH-WEIGHT RELATIONSHIPS, CONDITION INDEX AND SEX RATIO OF MUSSEL Lamellidens corrianus (Lea, 1834) IN A FRESHWATER LAKE, NORTHWEST BANGLADESH
}

\author{
Mostafizur Rahman Mondol*, Fouzia Nasrin, Dil Afroz Nahar \\ Department of Fisheries, Faculty of Agriculture, University of Rajshahi, Rajshahi 6205, Bangladesh \\ *Corresponding Author, Email: mostafiz_bau@yahoo.com
}

ARTICLE INFO

Received: 5 November 2015

Received in revised form: 7 April 2016

Accepted: 29 July 2016

Available online: 20 September 2016

\section{Keywords:}

Lamellidens corrianus

Length-weight relationship

Condition index

Bangladesh

\begin{abstract}
Allometry, condition index and sex ratio in freshwater mussel Lamellidens corrianus (Lea, 1834) were studied from the freshwater lake at Rajshahi, Northwest Bangladesh during the summer 2013. The collected mussel specimens ranged from $3.69 \mathrm{~cm}$ to $9.98 \mathrm{~cm}$ in length, and $4.82 \mathrm{~g}$ to $80.67 \mathrm{~g}$ in weight. The study was focused on the relationships between length-height and length-weights (length-total weight, length-tissue wet weight, length-shell wet weight, length-tissue dry weight and length-shell dry weight), which were found not to be significantly different between male and female $(P<0.05)$. The calculated regression equation of lengthheight relationship for the entire study period was $\mathrm{H}=0.5215 \mathrm{~L}-0.1482$ for combined sex. The equations of length-total weight, length-tissue wet weight, length-shell weight, length-tissue dry weight and length-shell dry weight relationships of mussel were $W=0.1756 \mathrm{~L}^{2.6775}, \mathrm{~W}=0.0261 \mathrm{~L}^{2.8919}$, $\mathrm{W}=0.0261 \mathrm{~L}^{2.5524}, \mathrm{~W}=0.0065 \mathrm{~L}^{2.8946}$ and $\mathrm{W}=0.095 \mathrm{~L}^{2.5109}$, respectively for combined sex. The relationships between length and height were linear, while that between length-weights follow the non-linear pattern. The overall male to female sex ratio was $1: 0.92$ and did not differ significantly from the expected 1: 1 ratio $\left(x^{2}\right.$-test, $\left.P<0.05\right)$. The condition index for male, female and combined sex was 13.54, 13.97 and 13.74, respectively. The results of this study will provide baseline information for fisheries researchers and for the further assessment and management of mussels in the freshwater ecosystems of Bangladesh.
\end{abstract}

How to Cite

Mondol, M. R., Nasrin, F., Nahar, D. A.(2016): Length-weight relationships, condition index and sex ratio of mussel Lamellidens corrianus (LEA, 1834) in a freshwater lake, Northwest Bangladesh. Croatian Journal of Fisheries, 74, 172-178.DOI: 10.1515/cjf-2016-0025.

\section{INTRODUCTION}

Among freshwater bivalves, Lamellidens corrianus (Lea, 1834 ) is an important species in the freshwater ecosystem of Bangladesh. It is widely distributed throughout Bangladesh, India and Nepal and also reported in Myanmar (Madhyastha et al., 2010). According to IUCN, L. corrianus is listed in the least concern category, although it is potentially susceptible to a number of threats, mainly fishing. The present sampling area indicates that the ethnic population from the Barind Tract, Northwest Bangladesh also regularly harvests bivalves for their own consumption. Currently, freshwater bivalves 
are becoming more important in Bangladesh since they are used in pearl production. Other threats viz. environmental degradation, habitat destruction, siltation, water pollution and agricultural run-off can also directly affect the mussel population. Therefore, a reduction in the diversity or abundance of freshwater mussels can indicate a negative change in the freshwater ecosystem.

Mollusks, like most organisms, exhibit progressive changes in their relative proportions with increasing body size. The allometric equation has also revealed extensive use in physiologicalinvestigation and in studies ofmussel production for estimating flesh weight relative to the measurement of shell length (Gosling, 1992). Shell dimensions or the volume of the animal is often used in growth estimation, as these methods are simple, non-destructive and can easily be performed in field conditions. When the allometric relationship is established, shell measurement is a sufficient substitute for estimating biomass and total flesh production (Hibbert, 1977). Studying mollusk's growth and establishing allometric relationships are necessary for successful resource management and understanding environmental conditions and pollution (Palmer, 1990). Information on allometry also helps in understanding the ideal conditions for bivalve's growth as well as to determine the size at which harvest can be intensified to maximize production. A number of studies have reported the allometric relationships of bivalves from different parts of the world (Nagabhushanam and Lomte, 1971; Alagarswami and Chellam, 1977; Nagabhushanam and Lohgaonkar, 1978; Lomte and Jadhav, 1980; Moorthy et al., 1983; Alunno-Bruscia et al., 2001; Ramesha and Thippeswamy, 2009; El-Sayed et al., 2011; Obirikorang et al., 2013; Suryawanshi and Kulkarni, 2014a, 2014b; Ramesha and Sofia, 2015). To the best of our knowledge, there is no information on allometric relationships of $L$. corrianus from Bangladesh. The present study was conducted to investigate the length-weight relationship, condition index and sex ratio of mussel $L$. corrianus inhabiting the freshwater ecosystem at Rajshahi, Northwest Bangladesh.

\section{MATERIALS AND METHODS}

The specimens of $L$. corrianus were collected during the summer of 2013 (June - August) from a freshwater lake located at Rajshahi $\left(24^{\circ} 22^{-} 21.56^{--} \mathrm{N}\right.$ and $88^{\circ} 38^{-}$ 11.16- E), Northwest Bangladesh. In total, 200 specimens were sampled. The mussel specimens were harvested by hand picking and transported to the laboratory alive, using polythene bags. The specimens were kept in aquarium for 24 hours and washed with clean water for removing the mud and epifauna from the mussel body. Shell length (maximum antero-posterior distance) and shell height (maximum distance from hinge to ventral margin) were measured up to $0.01 \mathrm{~cm}$ using vernirer calipers. Total weight was determined up to $0.01 \mathrm{~g}$ by using electric balance (ANDEK $300 \mathrm{H}$ capacity
$300 \mathrm{~g} \mathrm{~d}=0.01 \mathrm{~g}$ ). Mussels were then opened, tissue was removed from the shell and blotted to remove excess water in order to ensure accuracy before weighing the tissue. The individual weight of tissue and shell were then determined. Both, the tissue and shell were oven-dried at $60^{\circ} \mathrm{C}$ for 48 hours and weighed accurately using electronic balance (ANDEK $300 \mathrm{H}$ capacity $300 \mathrm{~g} \mathrm{~d}=0.01 \mathrm{~g}$ ).

Allometry was examined for morphometry (length-height) and length-weight (length-total weight, length-tissue wet weight, length-tissue dry weight, length-shell wet weight and length-shell dry weight) relationships according to Pauly (1983). The length-weight relationships were used to calculate the regression coefficient (slope of regression line of weight and length). The parameter $b$ of the length-weight relationships were estimated using the formula $W=a L^{b}$.

Where:

$\mathrm{W}=$ weight of the specimens in grams,

$\mathrm{L}=$ length of the specimens in centimeters

$\mathrm{a}=$ exponent describing the rate of change of weight with length

$\mathrm{b}=$ weight at unit length

The condition index (Cl) of mussel was calculated according to Lucas and Beninger (1985) using the following formula: Condition index $=[$ Tissue dry weight $(g) /$ Shell dry weight (g)] $x 100$

Sex was identified separately for each specimen. After removing the shell, smear was collected from the gonad and observed under microscope to determine the sex.

A student's t-test $(\mathrm{HO}, \mathrm{b}=3)$ was performed to determine statistical significance in the variation of $b$ values obtained by regression equations from the isometric value (Zar, 1999). When $b=3$, increase in weight is isometric. When the value of $b$ is other than 3 , weight increase is allometric (positive if $b>3$, negative if $b<3$ ) (Sokal and Rohlf, 1987; Thomas, 2013). The t-test was done using the equation $t s=(b-3) / \mathrm{Sb}$, where $t s=t$-test value, $b=$ slope, $\mathrm{Sb}=$ standard error of the slope (b). Subsequently, comparison between the obtained value of t-test and the tabled critical value of t-test allowed the determination of the statistical significance of the $b$ value. A chi-square test was employed to know the female to male equal representation (Zar, 1999). All statistical analyses were performed on SPSS Statistics 20.0 software at $P<0.05$ level of significance.

\section{RESULTS}

Table 1 illustrates sample size, minimum, maximum, mean value and $95 \%$ confidence limit of the biometric measurements. The mean shell length, shell height and total weight of mussel were $5.87 \pm 1.74 \mathrm{~cm}, 2.92 \pm 0.92 \mathrm{~cm}$ and $24.19 \pm 18.19 \mathrm{~g}$, respectively for males, $6.13 \pm 1.80 \mathrm{~cm}$, $3.04 \pm 0.96 \mathrm{~cm}$ and $26.90 \pm 19.0 \mathrm{~g}$, respectively for females, and $5.99 \pm 1.72 \mathrm{~cm}, 2.98 \pm 0.9 \mathrm{~cm}$ and $25.49 \pm 18.63 \mathrm{~g}$, respectively for combined sexes (Table 1 ). 
During this study, maximum shell length and total weight for the combined sexes were $9.98 \mathrm{~cm}$ and $80.67 \mathrm{~g}$, respectively. The mean condition index for males, females and combined sexes was $13.54 \pm 3.26,13.97 \pm 3.40$ and $13.74 \pm 3.40$, respectively (Table 2 ).

Condition index did not show any significant sex-specific difference. During this study sex was determinable for all specimens. Out of 200 collected specimens, 104 were males and 96 were females. A chi-square test revealed
1:0.92 male to female sex ratio, which was not significantly different from the 1:1 ratio (Table 3 ).

The dimensional length-height relationship of the shell was analyzed during the study period. It was found that the shell length and height increased in a linear pattern (Fig. 1).

However, a few individuals of the same length showed different heights. The calculated values of length-height relationship for the entire study period was $\mathrm{H}=0.5188 \mathrm{~L}-$ 0.1232 for males, $\mathrm{H}=0.525 \mathrm{~L}-0.1798$ for females and $\mathrm{H}=$

Table 1. Descriptive statistics on biometric data of $L$. corrianus (Lea, 1834) in the present study. $n$, sample size; Min, minimum; Max, maximum; SD, standard deviation; CL, confidence limit for mean values; SL, shell length; SH, shell height; TW, total weight; TWW, tissue wet weight; SWW, shell wet weight; TDW, tissue dry wet; SDW, shell dry weight

\begin{tabular}{|c|c|c|c|c|c|}
\hline Measurements & $\mathrm{n}$ & Min & Max & Mean \pm SD & $\mathrm{CL}_{95 \%}$ \\
\hline Male & 104 & & & & \\
\hline$S L$ & & 3.83 & 9.52 & $5.87 \pm 1.74$ & $5.54-6.20$ \\
\hline $\mathrm{SH}$ & & 1.85 & 5.12 & $2.92 \pm 0.92$ & $2.84-3.10$ \\
\hline TW & & 6.27 & 71.2 & $24.19 \pm 18.19$ & $20.69-27.69$ \\
\hline TWW & & 1.06 & 18.31 & $5.48 \pm 4.41$ & $4.53-6.33$ \\
\hline SWW & & 3.01 & 30.21 & $10.41 \pm 7.6$ & $8.95-11.87$ \\
\hline TDW & & 0.27 & 4.58 & $1.37 \pm 1.10$ & $1.26-1.58$ \\
\hline SDW & & 2.74 & 27.75 & $9.47 \pm 6.93$ & $8.18-10.76$ \\
\hline Female & 96 & & & & \\
\hline SL & & 3.69 & 9.98 & $6.13 \pm 1.80$ & $5.77-6.49$ \\
\hline $\mathrm{SH}$ & & 1.82 & 5.12 & $3.04 \pm 0.96$ & $2.85-3.23$ \\
\hline TW & & 4.82 & 80.67 & $26.90 \pm 19.10$ & $23.08-30.27$ \\
\hline TWW & & 1.08 & 20.34 & $6.15 \pm 4.61$ & $5.13-70.7$ \\
\hline SWW & & 2.05 & 36.23 & $11.64 \pm 8.34$ & $9.97-12.31$ \\
\hline TDW & & 0.27 & 5.09 & $1.54 \pm 1.15$ & $1.31-1.77$ \\
\hline SDW & & 1.81 & 35.56 & $10.69 \pm 7.68$ & $9.15-12.23$ \\
\hline Combined sex & 200 & & & & \\
\hline SL & & 3.69 & 9.98 & $5.99 \pm 1.77$ & $5.74-6.24$ \\
\hline $\mathrm{SH}$ & & 1.82 & 5.12 & $2.98 \pm 0.94$ & $2.85-3.11$ \\
\hline TW & & 4.82 & 80.67 & $25.49 \pm 18.63$ & $22.81-28.07$ \\
\hline TWW & & 1.06 & 20.34 & $5.80 \pm 4.51$ & $5.18-6.42$ \\
\hline swW & & 2.05 & 36.23 & $11.0 \pm 7.97$ & $9.90-12.10$ \\
\hline TDW & & 0.27 & 5.09 & $1.45 \pm 1.13$ & $1.39-1.61$ \\
\hline SDW & & 1.81 & 35.56 & $10.05 \pm 7.19$ & $9.05-11.05$ \\
\hline
\end{tabular}

Table 2. Condition index $(\mathrm{Cl})$ of $L$. corrianus (Lea, 1834) during the study period. Min, Minimum; Max, Maximum; SD, standard deviation; $\mathrm{CL}$, Confidence limit for mean values

\begin{tabular}{lcccc}
\hline \hline Sex & Min & Max & Mean \pm SD & CL 95\% \\
\hline Male & 7.44 & 24.07 & $13.54 \pm 3.26$ & $12.91-14.17$ \\
Female & 8.11 & 25.14 & $13.97 \pm 3.40$ & $13.29-14.65$ \\
Combined sex & 7.44 & 25.14 & $13.74 \pm 3.32$ & $13.28-14.20$ \\
\hline \hline
\end{tabular}


Table 3. Number of male, female and sex ratio (male: female) of mussel $L$. corrianus (Lea, 1834 ) during the study period

\begin{tabular}{|c|c|c|c|c|c|c|}
\hline \multirow{2}{*}{$\begin{array}{l}\text { Shell length } \\
\text { class (cm) }\end{array}$} & \multicolumn{3}{|c|}{ Number of specimens } & \multirow[t]{2}{*}{ Sex ratio (Male: Female) } & \multirow{2}{*}{$\begin{array}{c}X^{2} \\
(\mathrm{df}=1)\end{array}$} & \multirow[t]{2}{*}{ Significance } \\
\hline & Male & Female & Total & & & \\
\hline $3.00-3.99$ & 6 & 6 & 12 & $1: 1$ & 0.00 & ns \\
\hline $4.00-4.99$ & 49 & 38 & 87 & $1: 0.77$ & 1.39 & ns \\
\hline $5.00-5.99$ & 0 & 1 & 1 & - & 1.00 & ns \\
\hline $6.00-6.99$ & 10 & 9 & 19 & $1: 0.90$ & 0.05 & ns \\
\hline 7.00-7.99 & 25 & 23 & 48 & 1:0.92 & 0.08 & ns \\
\hline $8.00-8.99$ & 12 & 18 & 30 & 1:1.5 & 1.20 & ns \\
\hline $9.00-9.99$ & 2 & 1 & 3 & 1:0.5 & 0.33 & ns \\
\hline Overall & 104 & 96 & 200 & $1: 0.92$ & 0.32 & ns \\
\hline
\end{tabular}

NS, not significant; significant at $5 \%$ level $\left(X_{t 1,0.05}^{2}=3.84\right.$ and $1 \%$ level $\left(X_{t 1,0.01}^{2}=6.63\right)$

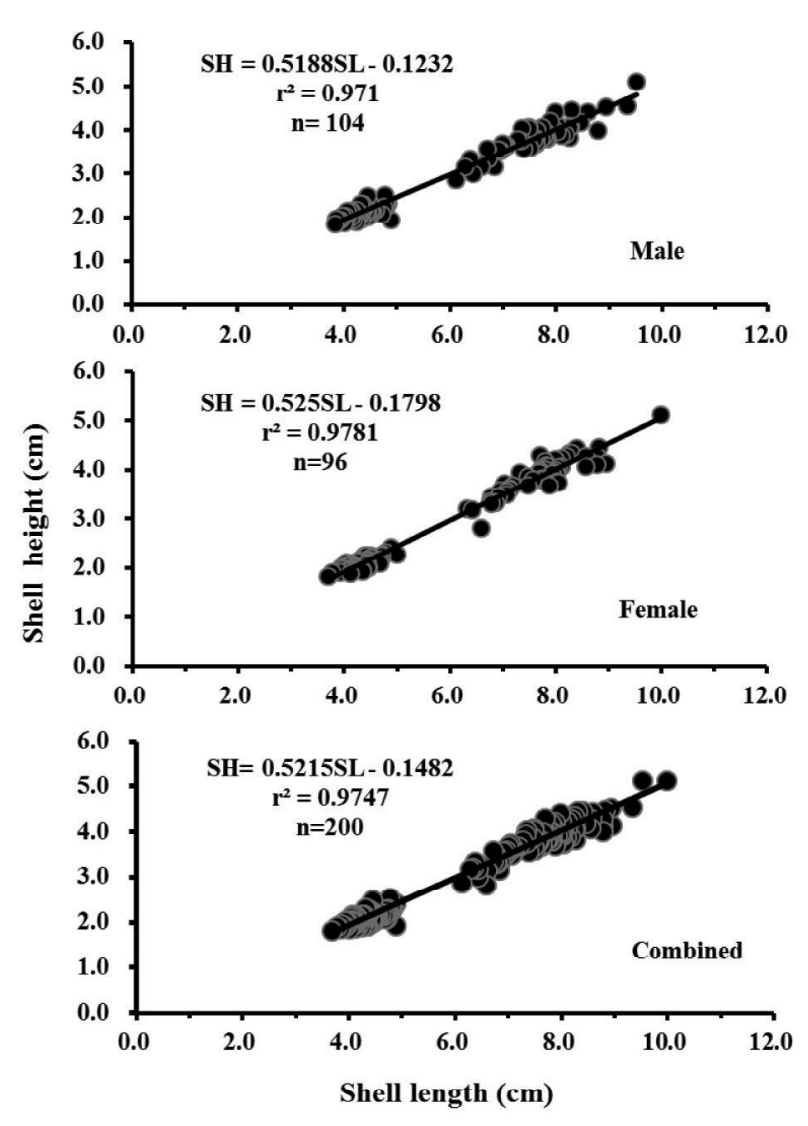

Fig 1. Length-height relationships for male, female and combined sex of $L$. corrianus during the study

$0.5215 \mathrm{~L}-0.1482$ for combined sexes (Fig. 1). The $b$ values of length-height relationship were 0.5188 for males, 0.525 for females and 0.5215 for combined sexes (Fig. 1).

Table 4 and Figure 2 represent the length-weight relationships of mussel during the study period. All length- weight relationships showed non-linear pattern and did not show any significant difference between males and females. During the study, length-total weight, lengthtissue wet weight, length-shell wet weight, length-tissue dry weight and length-shell dry weight relationships were $W=0.1783 L^{2.6706}, W=0.0244 L^{2.9289}, W=0.1 L^{2.5304}, W=$ $0.0061 \mathrm{~L}^{2.924}$ and $\mathrm{W}=0.1021 \mathrm{~L}^{2.4705}$, respectively for males, $\mathrm{W}=0.1723 \mathrm{~L}^{2.6862}, \mathrm{~W}=0.0282 \mathrm{~L}^{2.8518}, \mathrm{~W}=0.0917 \mathrm{~L}^{2.5765}, \mathrm{~W}=$ $0.0071 \mathrm{~L}^{2.845}$ and $W=0.0878 \mathrm{~L}^{2.5535}$, respectively for females, and $W=0.1756 L^{2.6775}, W=0.0261 L^{2.8919}, W=0.0261 L^{2.5524}, W=$ $0.0065 \mathrm{~L}^{2.8946}$ and $W=0.095 \mathrm{~L}^{2.5109}$, respectively for combined sexes (Table 4). The equilibrium constant (b) values of all length-weight relationships for both sexes were between 2.4705 and 2.9289 (Table 4, Fig. 2).

\section{DISCUSSION}

The present study is the first report on the allometric relationship in freshwater bivalve $L$. corrianus from a freshwater lake at Rajshahi, Northwest Bangladesh. The mussel population in this study showed a linear relationship between length-height. The morphometric relationships are used for comparison between dimensional growth of related species or the same species in different habitats (Hemachandra and Thippeswamy, 2008). In the present study, the $b$ value of length-height relationship was 0.525 for combined sexes. Ramesha and Sophia (2015) reported $a$ b value of 0.6742 for length-height relationship for freshwater mussel Parreysia favidens from India, and Ramesha and Tippeswamy (2009) reported a b value of 0.55118 for Perreysia corrugata from the River Kempuhole, India, an area comparable with the present study area. A variety of environmental factors are known to influence shell formation in bivalves, where size of shell is more affected by fluctuation of the ambient environment than their shape (Seed, 1968; Wilbur and Owen, 1964). Hence, shape, rather 
Table 4. Descriptive statistics and estimated parameters of the length-weight relationships of $L$. corrianus (Lea, 1834) from Rajshahi, Northwest Bangladesh. $\mathrm{n}$, sample size; TW, total weight; SWW, shell wet weight; TWW, tissue wet weight; TDW, tissue dry weight; SDW, shell dry weight; SL, shell length; $a$, intercept; $b$, slope; $r 2$, coefficient of determination; GT = growth type $(-A=$ negative,$+A=$ positive and $I=$ isometric growth)

\begin{tabular}{|c|c|c|c|c|c|}
\hline Sex & Equations & 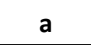 & b & $r^{2}$ & GT \\
\hline \multirow{5}{*}{$\begin{array}{c}\text { Male } \\
(n=104)\end{array}$} & $\mathrm{TW}=\mathrm{aSL^{b }}$ & 0.1783 & 2.6706 & 0.9927 & $-A$ \\
\hline & $S W W=a S L^{b}$ & 0.1000 & 2.53041 & 0.9708 & $-A$ \\
\hline & $T W W=a S L^{b}$ & 0.0244 & 2.9289 & 0.9715 & $-A$ \\
\hline & $\mathrm{TDW}=\mathrm{aSL^{b }}$ & 0.0061 & 2.9240 & 0.9714 & $-A$ \\
\hline & $S D W=a S L^{b}$ & 0.1021 & 2.4705 & 0.965 & $-A$ \\
\hline \multirow{5}{*}{$\begin{array}{l}\text { Female } \\
(n=96)\end{array}$} & $T W=a S L^{b}$ & 0.1723 & 2.6862 & 09938 & $-A$ \\
\hline & $S W W=a S L^{b}$ & 0.0917 & 2.5765 & 0.9722 & $-A$ \\
\hline & $T W W=a S L^{b}$ & 0.0282 & 2.8518 & 0.9689 & $-A$ \\
\hline & $\mathrm{TDW}=\mathrm{aSL^{ \textrm {b } }}$ & 0.0071 & 2.8450 & 0.9786 & $-A$ \\
\hline & $S D W=a S L^{b}$ & 0.0878 & 2.5535 & 0.9580 & $-A$ \\
\hline \multirow{5}{*}{$\begin{array}{c}\text { Combined } \\
\text { Sex } \\
(n=200)\end{array}$} & $\mathrm{TW}=\mathrm{aSL^{ \textrm {b } }}$ & 0.1756 & 2.6775 & 0.9983 & $-A$ \\
\hline & $S W W=a S L^{b}$ & 0.0960 & 2.5524 & 0.9715 & $-A$ \\
\hline & $T W W=a S L^{b}$ & 0.0261 & 2.8919 & 0.9701 & $-A$ \\
\hline & $\mathrm{TDW}=\mathrm{aS} \mathrm{L}^{\mathrm{b}}$ & 0.0065 & 2.8946 & 0.9641 & $-A$ \\
\hline & $\mathrm{SDW}=\mathrm{aS} \mathrm{L}^{\mathrm{b}}$ & 0.0950 & 2.5109 & 0.9770 & $-A$ \\
\hline
\end{tabular}
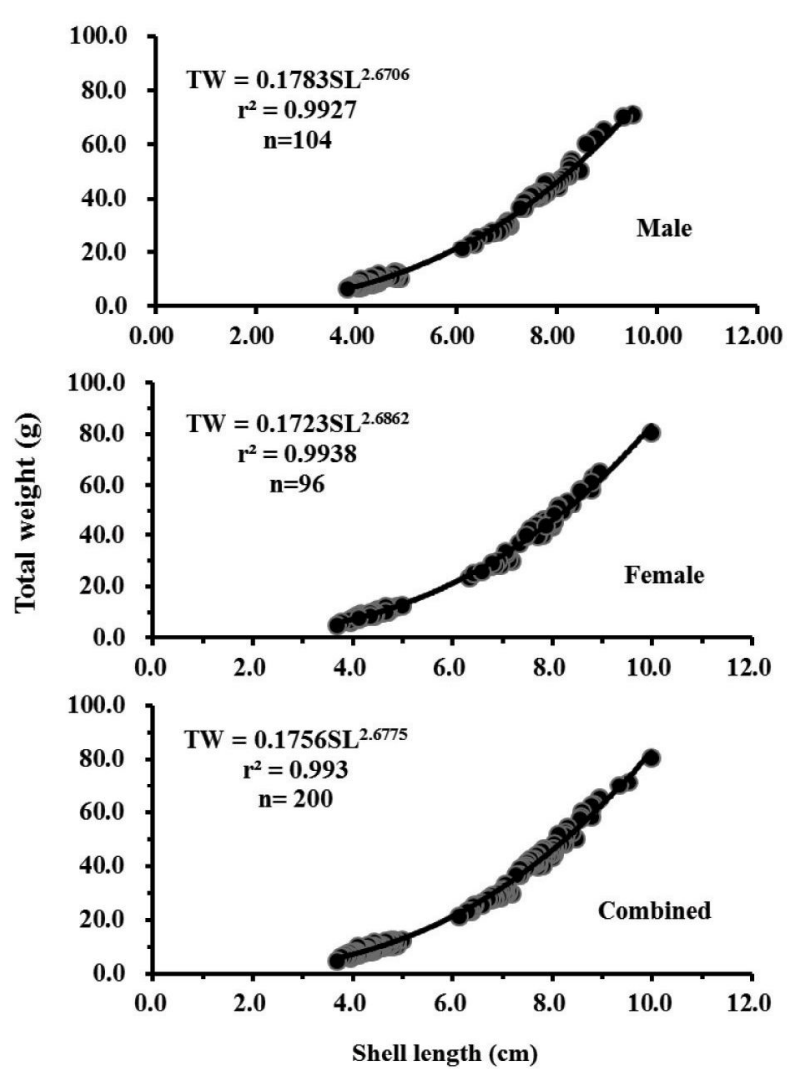

Fig 2. Length-total weight relationships for male, female and combined sex of L. corrianus in the present study than size, generally provides more precise information on the dimensional relationships (Hemachandra and Thippeswamy, 2008).

Growth in bivalves is often expressed as an increase in weight/volume and body size which are used as the most appropriate parameters for measurements (Seed, 1976; Bayne and Worrall, 1980). In length-weight relationship, the equilibrium constant (b) is the most interesting component and its variations from hypothetical unity suggest physiological variations in condition. When the weight at unit length $b$ is equal to 3 , growth is called isometric, and when it is less or greater than 3 it is allometric (Carlander, 1977; Sokal and RohIf, 1987). The fluctuations of b value in lengthweight relationship is directly related to the weight affected by ecological factors such as temperature, food supply, spawning conditions and other factors such as sex, age, sampling time and area (Wilbur and Owen, 1964; Seed 1968; Thippeswamy and Joseph, 1988; Boulding and Hay, 1993). In most of the bivalves, the $b$ value involving length and weight relationship lies between 2.4 and 4.5 (Wilbur and Owen, 1964; Shafee, 1978), with the exception of the worm-shaped species such as Terredo where a nearly linear relation $(b=1)$ was reported (Isham et al., 1951). In the present study, the estimated $b$ values of length-total weight, length-tissue wet weight, length-shell wet weight, length-tissue dry weight and length-shell dry weight relationships were 2.6775, 2.8919, 2.5524, 2.8946 and 2.5109, respectively for combined sexes. Malathi and Tippeswamy (2011) reported the $b$ values of length to total weight, length-wet weight, length-dry weight and length-shell weight were 2.6660, 2.6684, 2.9370 and 2.7124, respectively, for freshwater mussel Parreysia corrugata from the River Malthi in the Western Ghats, India. In addition, Ramesha and Tippeswamy (2009) reported the b values of length-total weight, length-wet weight, length-dry weight and length-shell weight were 2.777, 2.885, 2.805 and 2.832, respectively, for freshwater mussel Parreysia corrugata from the River Kempuhole, India.

During this study, no significant difference was observed between the length-weight relationships (length-total weight, length-tissue wet weight, length-shell weight, length-tissue dry weight and length-shell dry weight) of males and females of $L$. corrianus and the $b$ values of those relationships showed negative allometric growth patterns of mussel (see Table 4). Malathi and Thippeswamy (2011) also reported similar growth patterns (negative allometric) of freshwater mussel Parreysia corrugata from the River Malthi in the Western Ghats, India. The negative allometric growth in the present study might be linked to the reproductive strategy of bivalve (Desai and Borkar, 1989; Ramesha and Thippeswamy, 2009; Malathi and Thippeswamy, 2011; Thippeswamy et al., 2014). The present study was conducted in the summer, which is the most potential period for the reproduction of freshwater bivalves in Indian waters (Nagabhushanam and Lohgaonker, 1978; Malathi and Thippeswamy, 2011). In bivalves, gonadal 
growth and maturation enhance the bulkiness of soft tissue that resulted in an increase in body weights (Ramesha and Thippeswamy, 2009; Malathi and Thippeswamy, 2011). Consequently, when spawning occurs, gametes release, resulting in the shrinking of gonadal mass and lowering in body weights (Ramesha and Thippeswamy, 2009; Malathi and Thippeswamy, 2011). Obirikorang et al. (2013) studied the length-weight relationships of freshwater clam Galatea paradoxa from the Volta estuary, Ghana and reported negative allometric growth pattern between March and June and between December and February, when an indicative loss in tissue weight occurs as a direct result of spawning. Galtsoff (1964) and Etim et al. (1991) observed that the ripe clam gonad may comprise 31 to $41 \%$ of the total body weight and thus spawning results in an appreciable weight loss. According to the mentioned results, the detailed studies on reproductive biology and growth of $L$. corrianus are suggested.

\section{CONCLUSION}

The relationships of shell dimension of mussel $L$. corrianus are of the linear type and the relationships between length-weights followed the non-linear pattern during this study period. During this study, sex was differentiated for all specimens and the female to male sex ratio was not significantly different from 1: 1 ratio. The condition index for male, female and combined sex was 13.54, 13.97 and 13.74, respectively. This study is the first report on the length-weight relationships, condition index and sex ratio of $L$. corrianus from the freshwater ecosystem of Bangladesh. Further detailed studies on fisheries biology, including reproductive biology, growth and stock assessment, are recommended for the sustainable management and conservation of $L$. corrianus in the freshwater ecosystems of Bangladesh.

\section{ACKNOWLEDEMENTS}

We are grateful to the Department of Fisheries, Faculty of Agriculture, University of Rajshahi for providing facilities to carry out the research work. We would also like to express our sincere gratitude to the two anonymous reviewers for their valuable comments on the original draft which enabled us to substantially improve it. This study was in part supported by the grant from University Grant Commission, Bangladesh.

\section{Sažetak}

\section{DUŽINSKO-MASENI ODNOS, INDEKS KONDICIJE I OMJER SPOLOVA KOD DAGNJI, Lamellidens corrianus (LEA, 1834), U SLATKOVODNOM JEZERU NA SJEVEROZAPADU BANGLADEŠA}

Alometrija, indeks kondicije i odnos spolova kod slatkovodne dagnje, Lamellidens corrianus (LEA, 1834), iz slatkovodnog jezera u Rajshahi u sjeverozapadnom Bangladešu, proučavani su tijekom ljeta 2013. Prikupljeni su primjerci školjkaša u rasponu od $3,69 \mathrm{~cm}$ do $9,98 \mathrm{~cm}$ dužine i od $4,82 \mathrm{~g}$ do $80.67 \mathrm{~g}$ težine. Istraživanje je usmjereno između dužinsko-visinskih i dužinsko-masenih odnosa (dužinaukupna masa, dužina-tkivo mokre mase, dužina-ljuske mokre mase, dužina-tkiva suhe mase i dužine ljuske suhe mase) koji se nisu značajno razlikovali između mužjaka i ženki $(\mathrm{P}<0,05)$. Izračunata jednadžba regresije dužinsko-visinskog odnosa za cijelo izučavano razdoblje je bila $\mathrm{H}=0,5215 \mathrm{~L}-$ 0,1482 za kombinirani odnos spolova. Jednadžbe dužineukupne mase, dužine-tkivo mokre mase, dužine-mase ljuske, duljine-tkivo suhe mase i duljine-ljuske suhe mase dagnji imale su slijedeće odnose kod miješanih spolova: $W=0,1756 L^{2.6775}, W=0,0261 L^{2.8919}, W=0,0261 L^{2.5524}, W=$ $0,0065 L^{2.8946}$ i $W=0,095 L^{2.5109}$. Odnosi između duljine $i$ visine su bili linearni, dok su oni između duljine i mase slijedili nelinearne uzorke. Ukupni odnos mužjaka i ženki bio je 1: 0,92 i nije se bitno razlikovao od očekivanogomjera 1: 1 ( $x^{2}$-test, $\left.p<0,05\right)$. Indeks kondicije za mužjake i ženke je bio 13,54 , odnosno 13,97 , a miješani odnos spolova iznosio je 13,74. Rezultati ovog istraživanja pružaju osnovne informacije za znanstvenike iz područja ribarstva, kao i za daljnju procjenu i upravljanje dagnjama u slatkovodnim ekosustavima Bangladeša.

Ključne riječi: Lamellidens corrianus, dužinsko maseni odnos, indeks kondicije, Bangladeš

\section{REFERENCS}

Alagarswami, K., Chellam (1977): Changes of form and dimensional relationship in the pearl oyster Pinctada fucata from Gulf of Mannar. Indian Journal of Fisheries, 24, $1 \& 2$, $1-14$.

Alunno-Bruscia, M., Bourget, E., Fréchette, M. (2001): Shell allometry and length-mass-density relationship for Mytilus edulis in an experimental food-regulated situation. Marine Ecology Progress Series, 219, 177-188.

Bayne, B. L., Worrall, C. M. (1980): Growth and production of mussel, Mytilus edulis from two populations. Marine Ecology Progress Series, 3, 317-328.

Boulding, E. G., Hay, T. K. (1993): Quantitative genetics of shell form of an intertidal snail: constraints on short-term response to selection. Evolution, 47, 576-592.

Carlander, K. (1977): Handbook of Freshwater Fishery Biology, 1. lowa State University Press: Ames.

Desai, P. V., Borkar, M. R. (1989): A study of allometric relationship in Lamellidens corrianus. Indian Journal of Fisheries, 36, 2, 180-182.

El-Sayed, A. E. H., Fatma, A., Abdel-Razek, Abu-Zaid, M. M., Somaya, M. T. (2011): Measures of allometric growth of Black-lip pearl oyster Pinctada margaritifera (Linnaeus, 1758) Red Sea, Egypt. International Journal of Zoological 
Research, 7, 2, 201-211.

Etim, L., Akpan, E. R., Muller, P. (1991): Temporal trends in heavy metal concentrations in the clam Egeria radiata (Bivalvia: Tellinacea: Donacidae) from the Cross River, Nigeria. Revue d'Hydrobiolgie Tropicale, 24, 327-333.

Galtsoff, P. S. (1964): The American oyster Crassostrea virginica Gamlin. Fish Bulletin. Fish and Wildlife Service, United States, 64, 1-480.

Gosling, E. (1992): The mussel Mytilus: ecology, physiology, genetics and culture. Developments in aquaculture and fisheries science, 25. Elsevier: Amsterdam. ISBN 0-44488752-0. XIII, 589 pp.

Hibbert, C. J. (1977): Growth and survivorship in a tidal-flat population of the bivalve Mercenaria mercenaria from Southampton Waters. Marine Biology, 44, 71-76.

Hemachandra Thippeswamy, S. (2008): Allometry and condition index in green mussel Perna viridis (L.) from St. Mary's Island off Malpe, near Udupi, India. Aquaculture Research, 39, 16, 1747-1758.

Isham, L. D., Moore, H. B., Smith, F. G. W. (1951): Growth rate measurement of shipworms. Bulletin of Marine Sciences of the Gulf and Caribbean, 1, 2, 136-147.

Lomte, V. S., Jadhav, M. L. (1980): A study on the crystalline style of freshwater mussel, Parreysia corrugata. Hydrobiologia, 69, 175 - 178.

Lucas, A., Beninger, P. E. (1985): The use of physiological condition indices in marine bivalve. Aquaculture, 44, 187200.

Madhyastha, A., Budha, P.B., Daniel, B.A. (2010): Lamellidens Corrianus. The IUCN Red List of Threatened Species 2010: e.T166688A6259949. http://dx.doi.org/10.2305/IUCN. UK.2010-4.RLTS.T166688A6259949.en.

Malathi, S., Thippeswamy S. (2011): Morphometry, lengthweight and condition in Parreysia corrugata (Muller 1774) (Bivalvia: Unionidae) from river Malthi in the Western Ghats, India. International Journal of Biological Science, 1, 43-52.

Moorthy, K. S., Naidu, M. D., Chetty, C. S., Swami, K. S. (1983): Changes in carbohydrates metabolism in tissue of freshwater mussel (Lamellidens marginalis) exposed to phosphamidon. Bulletin of Environmental Contamination and Toxicology, 30, 219-222.

Nagabhushanam, R., Lohgaonker, A. L. (1978): Seasonal reproductive cycle in the mussel, Lamellidens carrianus. Hydrobiologia, 61, 9-14.

Nagabhushanam, R., Lomte, V. S. (1971): Biochemical studies in freshwater mussel, Parreysia corrugata. Hydrobiologia, 37, 545-552.

Obirikorang, K. A., Adjei-Boateng, D., Madkour, H. A., Amisah, S., Otchere, F. A. (2013): Length-weight relationship of the freshwater clam, Galateaparadoxa (Born, 1778) from the Volta estuary, Ghana. Pakistan Journal of Biological Sciences, 16, 185-189.

Palmer, A.R. (1990): Effect of crab effluent and scent of damaged conspecifics on feeding, growth, and shell morphology of the Atlantic dogwhelk Nucella lapillus (L). Hydrobiologia, 193, 155-182.

Pauly, D. (1983): Some simple methods for the assessment of tropical fish stocks. FAO Fisheries technology paper 234, $52 \mathrm{p}$.

Ramesha, M. M., Thippeswamy, S. (2009): Allometry and condition index in the freshwater bivalve Parreysia corrugata (Muller) from river Kempuhole, India. Asian Fisheries Science, 22, 203-214.

Ramesha, M. M., Sophia, S. (2015): Morphometry, lengthweight relationships and condition index of Parreysia favidens (Benson, 1862) (Bivalvia: Unionidae) from river Seeta in the Western Ghats, India. Indian Journal of Fisheries, 62, 1, 18-24.

Seed, R. (1968): Factors influencing shell shape in the mussel Mytilus edulis. Journal of Marine Biological Association United Kingdom, 48, 561-584.

Seed, R. (1976): Ecology. In: Marine mussels, their ecology and physiology. B. L. Bayne (Ed.). Cambridge University press: Cambridge, 13-66 pp.

Shafee, M.S. (1978): Studies on various allometric relationships in intertidal green mussel Perna viridis Linnaeus of Ennore estuary, Madras. Indian Journal of Fisheries, 23, (1\&2), 1-9.

Sokal, R.R., RohIf, F.J. (1987): Introduction to biostatistics, 2nd Ed. New York. W.H. Freeman and company, 363 pp.

Suryawanshi, A.V., Kulkarni, A.N. (2014a): Comparative study of length-weight relationship of Parreysia corrugata (Muller) and Lamellidens marginalis (Lamarck), from Nanded region, Maharashtra (India). Indian Journal of Life Sciences, 3, 2, 77-80.

Suryawanshi A.V., Kulkarni, A.N. (2014b): Length-weight, Length-Height, and Height-weight relationship of Parresia corrugata from Nanded Region. Indian Journal of Applied \& Pure Biology, 29, 1, 133-137.

Thippeswamy, S., Joseph, M. M. (1988): Seasonal variability in the condition of the wedge clam Donax incarnates (Gmelin). In: Joseph, M. M. (Ed.), Proceedings of the first Indian Fisheries Forum. Asian Fisheries Society, Indian Branch, Mangalore, 247-249 p.

Thippeswamy, S., Malathi, S., Anupama, N.M. (2014): Allometry and condition index in the freshwater bivalve Parreysia favidens (Benson, 1862) from river Bhadra, India. Indian Journal of Fisheries, 61, 4, 48-54.

Thomas, S. (2013): Allometric relationships of short neck clam Paphia malabarica from Dharmadom estuary, Kerala. Journal of Marine Biological Association of India, 55, 1, 50-54.

Wilbur, K. M., Owen, G. (1964): Growth. In: Physiology of mollusca, (K. M. Wilbur and C. M. Yonge, Eds.), 1, 211242. Academic Press, New York.

Zar, J. H. (1999): Biostatistical Analysis $4^{\text {th }}$ edition. Prentice Hall, New Jersey, USA. 663 pp. 